\title{
Chapter 8 \\ Essential Farmworkers and the Pandemic Crisis: Migrant Labour Conditions, and Legal and Political Responses in Italy and Spain
}

\author{
Alessandra Corrado and Letizia Palumbo
}

\subsection{Introduction ${ }^{1}$}

In recent years, institutional and scholarly attention has focused on the exploitation and systematic denial of the rights of workers - in particular migrant workers which underpins agri-food systems in many European Union (EU) countries, especially in southern European countries such as Italy and Spain (Corrado et al., 2018). In January 2020, just a few months before the Covid-19 pandemic hit Europe, the United Nations Special Rapporteur on the right to food, Hilal Elver, denounced the situation in Italy: 'from the North to the South of Italy, hundreds of thousands of workers farm the land or take care of livestock without adequate legal and social protections, coping with insufficient salaries and living under the constant threat of losing their job, being forcibly repatriated, or becoming the object of physical and moral violence' (Elver, 2020). In February 2020, following his visit to Spain, Philip Alston, the UN Special Rapporteur on extreme poverty and human rights, said: 'In Huelva, I met with workers living in a migrant settlement in conditions that rival the worst I have seen anywhere in the world. They are kilometres away from water, and live without electricity or adequate sanitation' (Alston, 2020).

The Covid-19 emergency has exacerbated this situation, revealing the precariousness of migrant labour in the agri-food system and, simultaneously, its essential role

\footnotetext{
${ }^{1}$ This chapter is the result of a common reflection of the two authors. However, Alessandra Corrado drafted Sects. 8.2 and 8.4 while Letizia Palumbo drafted Sects. 8.3 and 8.5. The Introduction and Conclusions (Sects. 8.1 and 8.6) were drawn up by both the authors. This publication has received funding from the Open Society European Policy Institute (OSEPI) and from the European Union's Horizon 2020 Research and Innovation programme (GA n. 870845 VULNER).
}

\author{
A. Corrado \\ Sociology of Environment and Territory, University of Calabria, Rende, Italy \\ L. Palumbo $(\triangle)$ \\ University of Venice Ca' Foscari, Venice, Italy
}

(C) The Author(s) 2022

A. Triandafyllidou (ed.), Migration and Pandemics, IMISCOE Research Series,

https://doi.org/10.1007/978-3-030-81210-2_8 
in this sector. Indeed, since the outbreak, a rise in the demand for essential goods has also meant that workers in key sectors such as agri-food have been recognised as fundamental to the economic and societal functioning of EU countries. At the same time, the pandemic has sharply disclosed the limits of long supply dynamics (in terms of price distortion, unfair competition, and distribution dynamics) as well as the conditions of exploitation and vulnerability experienced by many migrant farmworkers. An evident tension therefore has emerged between containing the pandemic through mobility restrictions, on the one hand, and preventing labour shortages (especially in core sectors) and addressing migrants' situations of vulnerability, on the other.

On 31 January 2020, Italy became the first EU member state to declare a state of emergency. This was followed by a series of government decrees in March establishing lockdown measures in the most affected zones aimed at containing the pandemic. These were then progressively extended to the entire country. The measures included closure of borders, high mobility restrictions and controls, hygiene and sanitary controls, and the closure of all commercial and retail activities except those deemed essential to coping with the emergency - such as the agri-food-sector. While in June 2020, the government lifted quarantine restrictions and reopened the borders, lockdown measures have been periodically implemented throughout the country. Indeed, at the time of writing Italy is still in a state of emergency.

In Spain, a state of emergency was enacted on 14 March 2020. This was then intensified on 27 March of the same year to be even more rigid for a further 15 days, during which a total ban on all non-essential work activities was established. In the case of Spain too the agri-food sector was declared strategic and therefore excluded from the so-called economic hibernation measures.

While the restrictions were progressively relaxed in June 2020, they continued to be adopted until Spring 2021. Indeed, the Spanish government declared the end of the state of emergency on 9 May 2021.

At the same time, both Italy and Spain, in line with other EU countries, adopted measures to respond to labour demand in key sectors, such as agri-food, and to face the situations of vulnerability of migrants employed in these sectors in a time of health and economic emergency. Both countries, in particular, drew the praise of the general public for adopting actions aimed at providing undocumented migrants with opportunity to regularise their legal status (Martín, 2020; Testore, 2020). However, despite the enthusiastic and optimistic tones, these interventions reveal shortcomings that significantly limit their impact and outcomes. This calls into question to what extent migrant workers are considered as really 'essential' in a long-term perspective and, above all, to what extent the current pandemic crisis constitutes an opportunity for a new national push to enforce labour rights and strengthen migrants' rights.

By focusing on Italy and Spain and building on extensive research carried out on working conditions of migrant farm workers, this chapter illustrates the characteristics and dynamics of migrant labour in the agri-food system, highlighting the impact of the Covid-19 crisis. It provides a critical comparative analysis of the legal and policy interventions adopted to tackle migrants' rights during the pandemic by paying special attention to the measures concerning migrants' situations of vulnerability. This contribution relies on the analysis of information collected through interviews with key stakeholders, legal and policy documents, and relevant 
literature and reports. The interviews were mainly carried out within a research project on the impact of the Covid-19 crisis on agri-food systems and migrant labour in EU countries which was commissioned by the Open Society European Policy Institute (OSEPI) and conducted by the Migration Policy Centre at the European University Institute (EUI) in May 2020 (Palumbo \& Corrado, 2020).

\subsection{Agri-Food Restructuring, Imbalances of Power, and Renewed Agrarian Conflicts}

Spain and Italy are the top European countries for number of specialised farms, cultivated area, and organic fruit and vegetable production, and for the highest number of farms overall (after Romania); together they accounted for about twofifths of the total value of the EU's fruit and fresh vegetable production in 2017 (Figs. 8.1, 8.2, and 8.3). They are also the two countries with the largest areas of
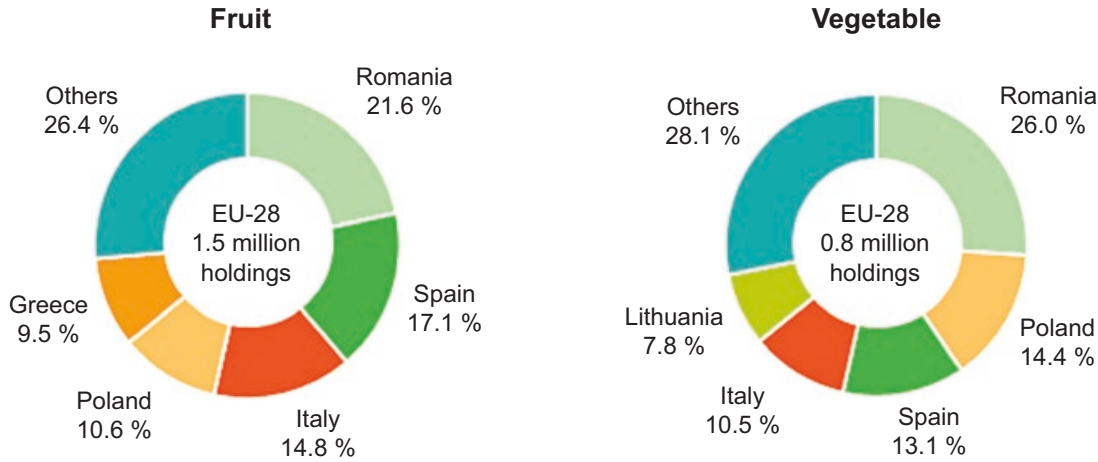

Fig. 8.1 Fruit and vegetable holdings by Member State, 2016 (\% of EU-28). (Source: Eurostat)

Fruit

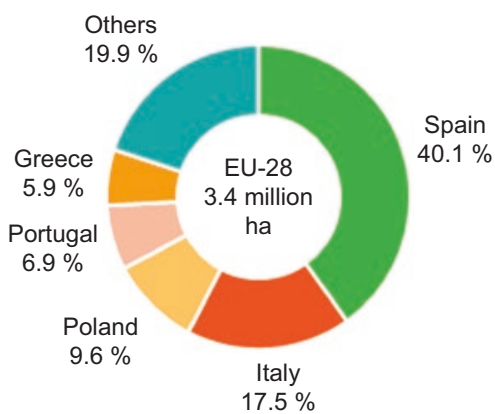

Vegetable

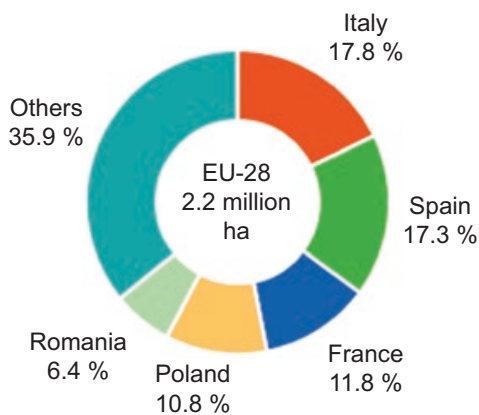

Fig. 8.2 Area of fruit and vegetable by main producing EU Member State, 2017 (\% of EU-28). (Source: Eurostat) 


\section{Fruit}

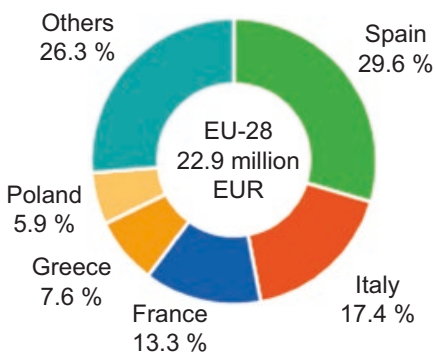

Vegetable

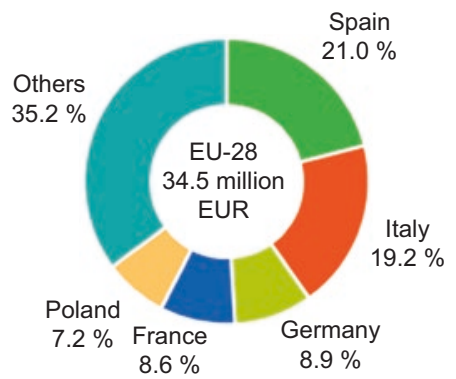

Fig. 8.3 Fruit and vegetable production value by main producing Member State, 2017 (\% of EU-28). (Source: Eurostat)

some production (tomatoes, oranges) and (with Poland) the highest value of tomato production. Fresh fruit and vegetables were traded mainly on the European market; Spain was the leading trader. Spain and Italy, together with the Netherlands, accounted for more than two-thirds of intra-EU exports in value terms and were responsible for over one-third of the total value of production in 2017 (Fig. 8.4). The EU as a whole was a net importer of processed fruit and vegetables, but some member states had record trade surpluses, including Spain and Italy (Eurostat 2019).

Both Spain and Italy have undergone a major restructuring of their agri-food systems, especially since the 1980s, within the dynamics of post-Fordist development and neo-liberal globalisation (Corrado, 2016). In Italy, the Common Agricultural Policy (CAP) served to support interventions for the modernisation of agriculture - i.e., the intensification of production, the enlargement of scale, the adoption of chemical inputs, varietal renewal, export orientation, entrepreneurship, and protection from foreign competition, at least until the early 1990s and the establishment of the European Single Market (1993). In Spain, on the other hand, agricultural modernisation had already begun before entry into the European Community (in 1986), under the Francoist regime, in the years 1950-1960, laying the foundations for the sector's industrialisation and the structuring of the country's main enclaves of production specialisation (e.g. Almeria and Murcia).

Through progressive reforms, following World Trade Organisation (WTO) agreements, the CAP has promoted competitiveness in global markets. Profit margins and market power in the agricultural sector have been severely weakened by the concentration process in the food industry, and the rapid expansion and centralisation of power in large-scale retailing systems. In line with the dynamics of the rearrangement of production processes on a global scale, agri-food supply chains in Italy and Spain are buyer-driven, with retail companies playing a central role in creating and managing a broad base of selected suppliers on which to build distribution systems. In 2017 supermarkets in Italy sold about 73.5\% of all food and drinks consumed. Market shares tend to be distributed among the various large-scale retail 

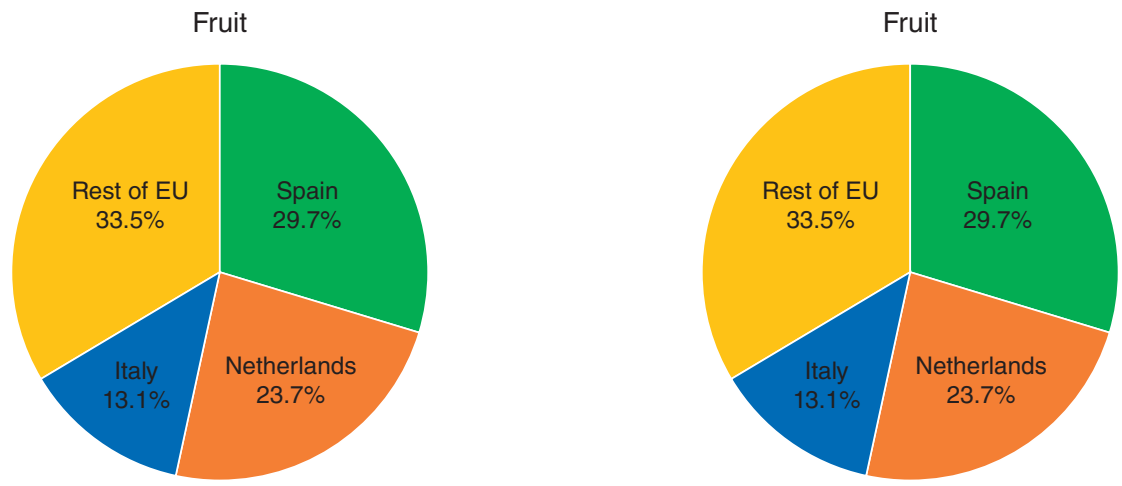

Fig. 8.4 Intra EU-28 Export of fruit and vegetable, 2017 (1000 EUR, 1000 tonnes). (Source: Eurostat)

operators. The top five companies jointly controlled just over $50 \%$ of the market in 2017, and of these three have a market share of over 10\% (Oxfam, 2018). In Spain, supermarkets and hypermarkets together controlled $82.3 \%$ of the food market in 2018 (ANGED, 2019); in 2019, Mercadona controlled 25.5\% of the food market (Kantar, 2020). However, it is worth noting that $80 \%$ of Spanish production is exported, while only $20 \%$ ends up in the domestic market - with large-scale retailers marketing just $7 \%$ of national production (Romera, 2020).

The process of concentration today is also articulated through the establishment of international super buying centres - alliances between the largest distribution groups aimed at obtaining better contractual conditions through collective negotiation with suppliers. The oligopolistic control of prices by the large international supermarket chains through continuous revisions and auctions on the reduction/ depreciation of products imposes an increasingly intense pressure on suppliers (Corrado et al., 2018).

Moreover, it is important to emphasise that, over the decades, in the light of a progressive process of defamilisation of agriculture or family deagrarisation (Arnalte-Alegre \& Ortiz-Miranda, 2013), the sharp reduction in the number of employees and farms resulting from these transformations has been matched by the growth of salaried work. The growing recruitment of migrant workers has certainly served to support the capitalist development of the agri-food system, that is, the continuous intensification, capitalisation, and innovation of agri-food production and processing, to cope with market pressures and the squeeze dynamics on producers' revenues. In both countries, Spain and Italy, therefore, the unequal relationship of global value chains has resulted in renewed agrarian conflicts (Perrotta, 2015; Perrotta \& Sacchetto, 2014; Reigada, 2021) and has rendered migrant labour both essential and exploitable.

Between 2019 and 2020, the agricultural sector in Spain was incited by a protest movement initiated by a group of the largest agricultural organisations Coordinadora de Organizaciones de Agricultores y Ganaderos (COAG), Unión de 
Pequeños Agricultores y Ganaderos (UPA), and Asociación de Jóvenes Agricultores (ASAJA) - against low prices paid to companies, increases in production prices, and the imbalance of power along the food value chain. In February 2020, the Leftwing Spanish government established a 5.5\% rise in the minimum interprofessional salary (Salario Minimo Interprofesional, SMI) over 2019, when it had been increased by $22.3 \%$ - that is, from $€ 735.90$ gross per month to 14 monthly payments of $€ 900$. This measure also provoked strong criticism, especially from the most capitalised farmers, ASAJA members, and employers' organisations from the main enclaves of intensive production (such as Murcia and Huelva) that opposed the SMI increase in the local collective agreements in agriculture (Pedreño Cánovas, 2020).

Pressure from the farmers between February and June 2020 further forced the Spanish government to amend Food Chain Law No. 12 of 2013 (Ley de la Cadena Alimentaria) in line with EU Directive 2019/633 on unfair trading practices in business-to-business relationships in the agricultural and food supply chain. Urgent measures on agriculture and food were introduced by the Royal Decree Law RD 5/2020 issued in February 2020, and a Draft Law No. 36-1 amending Law 12/2013 of 2 August on measures to improve the functioning of the food supply chain was approved by the Government on the 13 November 2020 (with the provision of entry into force in November 2021). The urgent measures made contracts obligatory in all transactions between producers and other actors in the chain; and prohibited sales at a loss and misleading offers at points of sale. In order to ban the destruction of value in the food chain, production costs have to be recorded and the price agreed by the producers and their first buyer has to be indicated in detail to ensure that sales prices are higher than production costs. The draft law extended the 'blacklist' of unfair practices, as well as the scope of sanctions and other measures to correct price imbalances harmful to farmers or stock breeders, and protection in international trade relations.

Similarly, in April 2021, the Italian Parliament approved the Law 53/2021 (2021 European Delegation Act) which delegates the Government to transpose the EU Directive 2019/633 on unfair trading practices in business-to-business relationships in the agricultural and food supply chain (Art. 7). In addition to being adopted with a significant delay, this law has introduced some criteria for the transposition of Directive 2019/633 that seem to be in contrast with the main approach of such EU instrument (Dongo, 2021).

Since 2019, the Parliament has also begun the process of approving a new law on 'ethical' agri-food chains (Draft Law 1373), that aims to contribute to the respect of farmworkers' rights, while providing consumers with tools to make informed food choices. The current draft law intends to define environmental, social and economic sustainability parameters, and provide tax relief and reward systems for agri-food companies that contribute to the creation of ethical chains, including those companies that join the Network of Quality Agricultural Work, which was established by Legislative Decree No. 91/2014 to recognise and support companies that respect fair labour and employment conditions in the agricultural sector. Furthermore, this draft law has introduced production traceability systems. 


\subsection{Migration Policies, Migrant Labour Composition, and Working Conditions}

This section offers a critical overview of the relevant policies and legislation on migration in Italy and Spain, as well as information about migrant labour composition and working conditions in the agri-food systems in these two countries. The aim is to provide the background against which the pandemic crisis exploded.

Being characterised by an historical tradition of emigration, and with a recent history of immigration, Italy and Spain have been defined as emblematic of the 'Mediterranean model of migration' (King et al., 2000). This is marked by a high element of 'irregularity', in which employment in the agricultural sector represents one of the main channels for migrants to access the labour market. Since the late 2000s, this model has been challenged by several factors such as the European enlargement process, the economic crisis and the so-called refugee crisis. The impact of these factors, together with the inadequacies of national systems of recruitment of foreign workers, has reflected a change in migratory movements and, accordingly, in the composition of migrant labour. This is especially evident in sectors such as agri-food which are marked by a high segmentation of labour on the basis of nationality, class, and gender, and by downward competition in terms of wages and labour rights.

In Italy, under Law No. 40/1998, the entry system for foreign workers is based on an employer-driven mechanism requiring a specific request from a resident employer. This system, which sets annual quotas for different categories of workers via government decree (Decreto Flussi), has proved inadequate and resulted mainly in 'ex post regularisations' and abusive practices. Furthermore, since 2011, quotas for non-seasonal workers have been drastically limited, while quotas for seasonal workers have been cut by almost half (Corrado et al., 2018).

In this context, the lack of an effective entry system for foreign workers capable of meeting labour demand in sectors such as agriculture has been offset mainly by migrants from eastern EU member states, undocumented workers, and, especially since 2015, by non-EU asylum seekers and refugees (Corrado et al., 2018). As several studies have highlighted, the different situations of vulnerability of these categories of migrants seems to translate into a variety of forms of exploitation (Palumbo $\&$ Sciurba, 2018).

According to official data, Romanians are one the largest groups of farmworkers in Italy, involving a significant presence of women (CREA, 2019). In some areas, Romanians have 'replaced' African migrant workers as their wages are lower and they tend not to be unionised and are viewed as a less-empowered labour force. Thus, despite being able to freely move within the EU, Romanians often work under harsh and exploitative conditions. For instance, in the case of the agri-food district in Ragusa, Romanian labourers work between 10 and $12 \mathrm{~h}$ per day in unsafe conditions for a meagre wage and live in crumbling shelters in the greenhouses, often with their children. In this scenario of isolation and dependency on employers, women's labour exploitation is often accompanied by sexual blackmail and abuse 
by employers and gangmasters. Women with family responsibilities in particular seem to be the most exposed to abuse (Palumbo \& Sciurba, 2018).

While Romanian farmworkers are employed in both seasonal and permanent agricultural production (as in the case of the greenhouses in Ragusa), asylum seekers and refugees as well as undocumented migrant workers are mainly involved in seasonal cultivation, moving from one harvesting zone to another across the country.

Some scholars have talked about a process of 'refugeesation of the agricultural workforce' (Dines \& Rigo, 2015) to highlight the rising number of refugees and asylum seekers employed in agriculture. For asylum seekers especially, the interplay between the inadequate implementation of asylum procedures and the absence of appropriate hosting and inclusion measures in the country has produced a condition of 'hyper precarity' (Lewis \& Waite, 2015) that fosters their exposure to dynamics of exploitation. This situation of vulnerability has been further exacerbated by the provisions of the so-called Security Decree or Salvini Decree' (Decree Law No. 113/2018 converted into Law No. 132/2018), which was adopted in October 2018. Building on an emergency-based approach to migration, the Security Decree abolished the residence permit for humanitarian reasons (known as 'humanitarian protection'). This form of protection had been established by Legislative Decree No. 286/98 (Consolidated Act on Immigration) to protect people in situations of vulnerability who are non-eligible for refugee status or subsidiary protection but could not be expelled from the country because of 'serious reasons of humanitarian nature or resulting from constitutional or international obligations of the State'. The abolition of humanitarian protection has led to a significant increase in the number of irregular migrants (Geddes \& Pettrachin, 2020, 238).

The Security Decree also excluded asylum seekers from the decentralised state reception system SPRAR (Sistema di Protezione per Richiedenti Asilo e Rifugiati), renamed SIPROIMI (Sistema di protezione per titolari di protezione internazionale e per i minori stranieri non accompagnati), which supports social and labour inclusion for migrants. Asylum seekers have therefore been crammed into emergency reception centres known as CAS (Centri di Accoglienza Straordinaria), many of which lack adequate structures and services, fail to meet basic hygiene and safety conditions, are overcrowded, and do not provide effective inclusion programmes. Moreover, some of these centres are in isolated rural areas and have become a pool of cheap and easily exploitable migrant farmworkers (Corrado et al., 2018).

At the same time, thousands of migrants, including seasonal workers, asylum seekers, beneficiaries of international protection, and undocumented migrants, live in informal settlements (MSF, 2018) without basic services such as access to water and sanitation. As discussed below, the degrading conditions of these informal camps as well as the inadequacies of the institutional reception centres have raised serious concerns during the pandemic.

Exploitation and social and spatial ghettoisation are also common elements in Spain. According to official data, in 2017 migrant workers constituted roughly $23.2 \%$ of the total salaried agricultural workforce (Cuesta \& Sánchez, 2017). However, as in the case of Italy, these statistics cannot provide an effective depiction 
of reality given the significant presence of undeclared work in the agri-food sector. Migrant farmworkers are mainly concentrated in the southern areas of the country, and their employment is characterised by a market of internal circular mobility linked to the harvest period, moving, for example, between Murcia, Alicante, Albacete, Huelva, and Alméria, or Barcelona and the provinces of Tarragona and Girona (Viruela \& Torres Pérez, 2015).

As for recruitment system of foreign seasonal workers, in Huelva and Lleida one of the main institutional mechanisms for the employment of third-country migrant farmworkers is the so-called 'contract in origin' or 'at source' (contratación en origen), within defined annual quotas, as established by the Law on the Rights and Freedoms of Foreigners (Ley Organica No. 4/2000). Migrants are recruited directly in their country of origin, arriving in Spain having already signed a contract for specific employment with pre-set working and social conditions. Returning home at the end of the contract is a conditional criterion for reapplying for other 'contracts in origin' within the next year's quotas.

The first trial of the 'contracts in origin' mechanism was based on bilateral agreements between Spain and eastern European countries, in particular Romania, in the early 2000s. Recruitment mainly involved female workers who, in accordance with gender and social stereotypes, were considered more 'docile' and culturally similar than African males (Hellio, 2016).

Contrary to what happened in Italy (especially in rural areas like Ragusa), EU enlargement in 2007 resulted in a decrease in EU migrant workers in the Spanish agri-food sector in districts such as Huelva. Romanian and Polish female farmworkers in particular were almost entirely replaced by Moroccan women employed through 'contracts in origin'. In this case, the fact of having left young children in the country of origin was an explicit formal prerequisite to be selected, as it was considered a guarantee of their return to the country of origin at the end of the harvest (Palumbo \& Sciurba, 2018).

But similar to Italy, in Spain too agriculture has become a refuge sector for migrants, especially Africans, as a consequence of the 2008 economic crisis (Pedreño Cánovas, 2020). At the same time, the economic crisis affected the system of 'contracts in origin' with a decrease in quotas and contracts since 2011. This has in turn led to an increase in the presence of EU migrant workers. In particular, Romanian farmworkers have become, once again, one of the largest components of migrant labour in the Spanish agri-food sector (Caruso, 2016); many are women, usually recruited through temporary work agencies (Molinero Gerbeau, 2018) and often in conditions of exploitation.

Yet, 'contracts in origin' is still the main path for farmworkers' (women) recruitment from third countries in the areas of Huelva and Lleida. This model has been criticised for creating a strong worker dependency on employers, leading workers to be more 'docile' and willing to accept abusive work conditions. Moreover, within this system, care relations and family responsibilities have formally become elements used as a guarantee of the recruitment of a vulnerable, flexible, and feminised labour force. While in some Italian contexts, such as Ragusa, similar dynamics emerge as a consequence of the interplay between inadequate entry systems, new 
composition of migratory movements, and the requests of employers, in Huelva these seem to be facilitated by institutional policies. Several studies have reported how the 'contracts in origin' model has fostered specific forms of gender-based exploitation and abuse, ranging from arbitrary deductions of a percentage of wages and excessive unpaid overtime to sexual assault and exploitation (Palumbo \& Sciurba, 2018). As discussed below, this situation of dependency and vulnerability has been exacerbated by the Covid-19 lockdown.

\subsection{The Pandemic's Effects on the Agri-Food Sector and Migrant Labour Conditions}

In both Italy and Spain lockdowns and other measures taken to stem the pandemic significantly hit the hotels, restaurants, and catering sector, or 'Horeca'. This in turn affected the demand for agricultural products, especially 'quality products' such as cheeses and wines. In Italy the sector's losses were around €34 billion. A drop in seasonal products - i.e., tomatoes, strawberries - was recorded, but a rise in demand for domestic food consumption and a drop in imports helped maintain or in some cases boost products' prices (ISMEA, 2020; MAPA, 2020). However , employment rates in Italy's agricultural sector remained close to 2019 levels and have been rising since May, revealing good stability relative to other sectors (Mlps et al., 2020).

In Spain, by contrast, agricultural employment has been significantly impacted by Covid-19, with migrant labourers particularly hit as the jobs in the sector shrunk to 791,163 in 2020 from 808,255 in 2019 (Ministerio de Inclusión, Seguridad social y Migraciones, 2020a, b). Even so, there has been substantial employment stability in the enclaves of intensive agriculture, such as Huelva, Almeria, and Murcia.

The pandemic border restrictions and lockdown have led national farmers' organisations to sound the alarm on labour shortages, especially of eastern European workers (mainly Romanians), highlighting the agri-food sector's dependence on cheap and flexible migrant labour - one of the results of power imbalances in long supply chains. However, labour shortages in many areas have been offset by a reserve army of migrant labour in situations of irregularity and vulnerability, and through dynamics of work intensification.

In Spring 2020, farmers' organisations asked for the establishment of special 'green corridors' facilitating the mobility of seasonal workers within the EU, according to the EU Commission on the free movement of workers during the crisis (European Commission, 2020a, b). In Italy, this proposal was supported by the Italian Minister of Agriculture, Food and Forestry. However, despite numerous bilateral meetings, no concrete agreements were reached with Romania. National emergency measures did not provide for 'active quarantine' - i.e. the possibility for foreign seasonal workers to spend their quarantine working in the fields albeit at a distance from other workers. This measure has been adopted by Germany, with the result of attracting many Romanian farmworkers, also because of the higher wages (Cappellini, 2021). 
Since the beginning of the pandemic, companies or producer organisations have arranged the transport of groups of seasonal workers by charter flights to countries such as Italy from Morocco or to Spain from Uruguay. In Italy, especially in the northern regions, businesses have looked for workers through employment agencies or local employment centres (Macrì, 2020).

As has emerged in the case of Italy, the lockdown measures initially made it impossible for many migrant farmworkers, especially those without a residence permit or a regular contract (mainly Sub-Saharan Africans) to move and access farms. Lockdown measures also undermined the actions of illegal gangmasters (so-called caporali), who in some zones of Italy maintain near-total control - in an exploitative way - over the recruitment, transportation, and accommodation of farmworkers. Gradually, the situation has changed as police and labour inspectorate controls have been relaxed, allowing caporali to move and transport workers to complete the harvest, such as in the area around Foggia, or farmers to hire irregular workers (interview with R. Falcone, trade union Flai Cgil, 17 June 2020).

In Spain, border restrictions have meant serious repercussions for the "contracts in origin' system. Before the state of emergency, only 9000 of the 24,000 workers from Morocco who had initially been contracted entered Spain. When the harvests ended, the Moroccan government prohibited the return of the (mostly female) workers who remained 'immobilised' in the Spanish countryside with no means of subsistence and were supported solely by trade unions (Echevarría, 2020). In other words, the pandemic has put the spotlight on the reality of a system built on dependence on employers and gendered dynamics and power relations.

Moreover, since the lockdown, there has been an intensification of rhythms in the fields; conditions have been more abusive, with workers having to harvest larger quantities of produce and to do more overtime, such as in Huelva (interviews with A. Pinto, Jornaleras de Huelva en Lucha, and S. Gorsky, Instituto Joaquín Herrera Flores, 29 June 2020; interviews with A. Márquez Tejón and H. Wilson, Women's Link Worldwide, 30 June 2020). The Jornaleras de Huelva en Lucha collective, in collaboration with the Abogadas Sociedad Cooperativa association, urged state institutions to intervene and raised several complaints against companies and local authorities for non-compliance with safety regulations to protect workers.

In Italy, trade unions have also reported a lack of compliance with safety protocols in the countryside. Few businesses have provided workers with masks and enforced safety measures. Several complaints were addressed by workers, especially in packaging warehouses (interviews with G. Scifo, Cgil, 19 June 2020 and R. Falcone, Flai Cgil, 17 June 2020).

In both Italy and Spain, the degrading living conditions of migrant farmworkers raise even more concerns in a pandemic. In the informal camps where many migrant farmworkers settle, personal protection measures have been practically impossible to implement due to a lack of drinking water, electricity, and essential minimum services, as well as precarious and overcrowded housing conditions. In both the countries, trade unions and humanitarian organisations have supported agricultural workers by distributing drinking water, essential goods, and personal protective equipment to informal settlements such as the Sindicado Andaluz de Trabajadores 
(SAT) in Hueva and Almeria, or Unione Sindacale di Base (USB) in Foggia and in the Plane of Gioia Tauro-Rosarno.

Various outbreaks of Covid-19 have been reported. In Spring 2020, the contagion spread to the industrial animal slaughtering sector, as in Bari (Italy) and Huesca (Spain), but then gradually affected mobile seasonal labourers housed in informal ghettos or collective dormitories. The temporary work enterprise Terra Fecundis, based in Murcia (Spain) but operating across interprovincial or national borders, was investigated in France for the Covid-19 outbreaks triggered by seasonal workers in Provence.

On the other hand, there have been migrant workers' demonstrations in both countries: for instance, in May 2020, in Italy (in particular, in Foggia) hundreds of migrant workers went on strike to demand a strengthening of their rights; in July 2020 in Spain, migrant farmworkers took the streets to protest against the confinement imposed on an informal settlement and claim the need to work in order to meet their livelihood (as in Albacete, Castilla-La-Mancha), or demand decent housing in (Lepe, Huelva) (Summers, 2020).

In June 2020, a coronavirus outbreak hit Bulgarian Roma farmworkers living in degraded buildings in Mondragone (Italy). This situation - and the ensuing lockdown of the entire residential area - triggered protests and clashes with the Italian inhabitants. In October of the same year, the spread of infections in the crowded emergency camps in the Plane of Gioia Tauro-Rosarno (in the province of Reggio Calabria) resulted in the confinement of hundreds of migrant workers (Fig. 8.5).

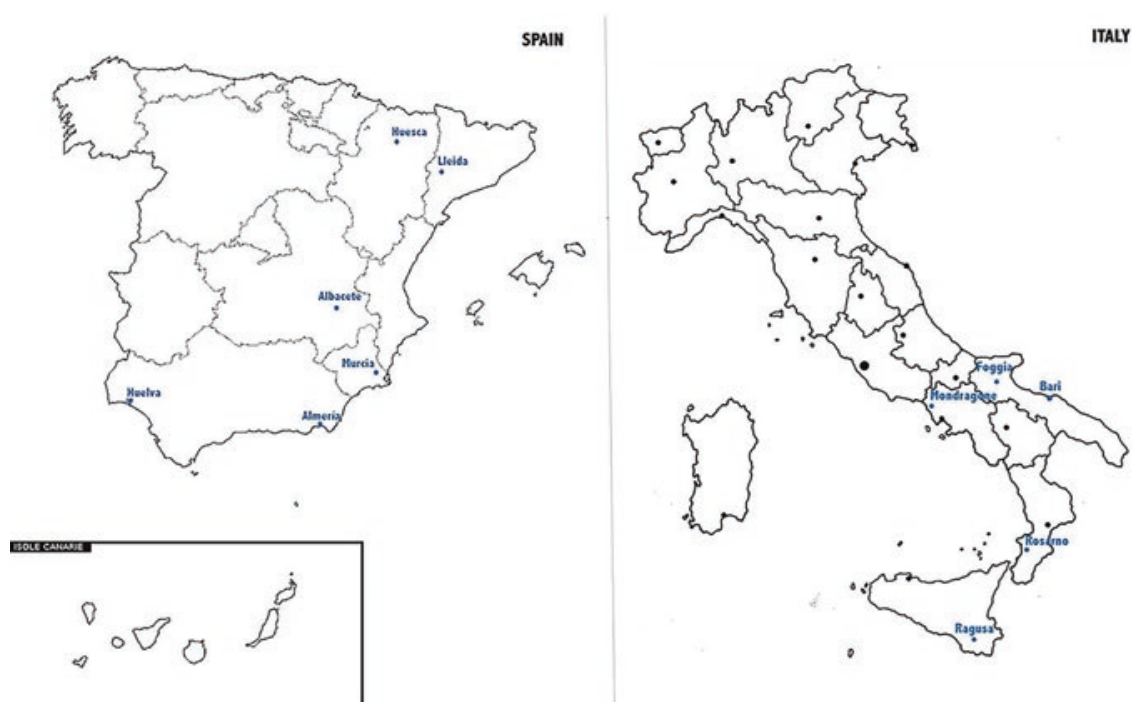

Fig. 8.5 Maps of main Covid-19-related infections and mobilisations involving migrant farmworkers in Italy and Spain. (Source: own elaboration) 


\subsection{Legal and Political Responses to Address Migrant Farm Workers' Situations of Vulnerability During the Pandemic}

In response to alarm about labour shortages, and to address the situations of vulnerability of many migrant farmworkers, Italy and Spain have adopted several measures to support the agri-food sector and to facilitate the mobility and recruitment of seasonal migrant workers and guarantee them adequate and safe services during the pandemic .

In Italy, in March and April 2020, the government adopted some measures to provide a financial support package during the crisis, also covering the agri-food sector. It established an increase from $50 \%$ to $70 \%$ in advance payments from the CAP, as well as incentives for exports. The measures also provide for a two-month $€ 600$ transfer to agricultural workers on short-term contracts, subsidised lay-offs for all employees in the sector, and rolled out social protection for seasonal workers. However, many migrant farmworkers who were employed informally could not benefit from these subsidies (Palumbo and Corrado 2020).

With respect to alarm about labour shortages, in Italy most of the institutional attention focused on the adoption of a plan to regularise undocumented migrants. The regularisation scheme was adopted after intense debate, with some misgivings within the governing coalition and opposition from the far-right Lega and Fratelli D'Italia parties. This provision, entitled 'Emergence of Employment Relationships', was included in the so-called Relaunch Decree (in particular in Article 103) approved by the Italian government on 13 May 2020 for a post-pandemic economic recovery (Law-Decree n. 34 of 19/05/2020 converted into Law n. 77 of 17 July 2020). The provision aimed to 'ensure adequate levels of individual and collective health protection' as a consequence of the health emergency, and to 'facilitate the emergence of irregular employment relationships', applying only to the agri-food, care and domestic work sectors. It aimed to cover all those doing undeclared work, whether undocumented foreign workers, Italian citizens, EU migrants, or regular non-EU migrants.

The provision established two application channels and a 15 July 2020 deadline, which was subsequently extended to 15 August 2020. The first channel allowed employers to apply to conclude a fixed-term employment contract for foreign nationals or declare the existence of an irregular employment relationship with Italian citizens or foreign nationals. Foreign citizens must have been present in Italy before 8 March 2020 and must not have left the country since that date. In the case of undocumented migrants, they received a residence permit for work reasons.

The second channel allowed foreign citizens with a residence permit that had expired since 31 October 2019, who were able to prove they worked in one of the eligible sectors before that date and who had been present in Italy before $8 \mathrm{March}$ 2020 , to apply for a six-month temporary residence permit to look for a job in these sectors. This temporary permit can be converted into a residence permit for work reasons. 
In both channels, if the employment relationship terminates, even in the case of a seasonal contract, foreign nationals have the possibility of applying for a one-year residence permit while 'awaiting employment'.

It might be argued that given the Italian government's hesitant and restrictive approach to migration, this regularisation could be considered a step forward. However, since the beginning it has been clear that significant inadequacies would affect its impact, resulting in a limited number of regularised migrants, especially migrant farmworkers.

In line with the previous regularisation schemes, the plan has mainly relied on an employer-driven approach, providing a limited space of action for the workers. The limits of this approach are particularly evident for cases characterising the agri-food sector, where irregular recruitment of workers is connected to exploitation of workers in a situation of vulnerability. The Decree does suspend some ongoing criminal and administrative proceedings against employers; however, this has not been sufficient to sway employers who find it more convenient to use undeclared workers (Palumbo, 2020; Schiavone, 2020).

With regard to the second channel, a temporary residence permit to look for work is a relative novelty for the Italian legal system which, since 2002, has closely linked residence permits to the existence of a labour contract and channelled foreign workers into the above-mentioned inadequate entry mechanism (see above 'Migration policies' section). However, prerequisites for this second path significantly limited its scope, leaving out numerous migrants in situations of irregularity and precariousness, including many of those affected by the so-called Security Decrees.

Lastly, by applying only to the agri-food and domestic/care sectors, the plan overlooked sectors such as logistics, construction, tourism, and food services that have high rates of undeclared work, including by migrants in irregular and exploitative conditions. This decision clearly highlighted the economic and labour market logic behind this regularisation.

According to official data provided by the Italian Minister of the Interior (Ministero dell'Interno, 2020), there have been 220,528 applications for both channels of regularisation: respectively, 207,542 for the first channel, and mainly in the domestic and care work sector (that is $85 \%$ of the total number of applications), and 12,986 for the second, and basically in agriculture (that is $15 \%$ of the total). Interestingly, 64\% of applications in domestic and care work concern foreign men. Given the high percentage of women in this sector, the latter datum suggests that there have been abusive practices such as sale of 'false' contracts to allow people to access to regularisation (Rondi, 2021).

The number of accepted applications is not yet known or estimated. However, it is worth underlining that, while there is a correspondence between the number of applications estimated by government and the real number of applications, 220,000 is only a fraction of the estimated 600,000 undocumented migrants (Fondazione Ismu, 2020) at risk of marginalisation and exploitation. Moreover, the regularisation seems also to have had a limited impact for specific sectors covered by the scheme: around 46,000 migrants irregularly employed in agriculture and some 132,000 
migrant workers in care and domestic work have not benefited from the regularisation (Schiavone, 2020, 133).

At the time of writing, the processing of the applications has proceeded at an unbelievably slow pace (in May 2021, only 12,7\% of the applications were examined). This, in turn, has resulted in a slow number of residence permits that have been issued: with regard to the first channel, at the end of 2020, only 1480 residence permits were issued throughout Italy $(0.71 \%$ of the total $)$, while in the case of the second path, data are slightly better as in the same time frame 8887 residence permits were issued (68\% of the total) (Ero straniero, 2021). Although migrant workers are allowed to work while waiting for the processing of their applications, this condition of uncertainty leaves them in a limbo that increases their situations of vulnerability.

The Relaunch Decree (Article 103) also provided that competent national and regional authorities adopt - including through the implementation of the measures established by the 2020-2022 national Plan against exploitation in the agricultural sector and illegal gangmastering - interventions and actions to guarantee adequate and safe accommodation and services, as well as to combat undeclared work and exploitation. These measures should also be adopted in accordance with the actions provided by Law N. 199/2016 addressing labour exploitation and illegal gangmastering, which constitutes an important milestone in the fight against exploitation but is still inadequately implemented, especially in respect to the development of the above-mentioned Network of Quality Agricultural Work at national and local levels (Corrado et al., 2018).

Far from implementing structural actions, at the time of writing, only emergencybased interventions have been developed in a few rural areas of Southern Italy, providing migrant workers in the informal settlements with water, food, health and legal assistance, and temporary housing structures.

In October 2020, the Italian government issued a new Decree Law No. 130/2020 on migration and international protection, which was converted into Law No. 173/2020 by Parliament on 18 December 2020. The Decree has significantly changed some provisions of the so-called Security decrees, ${ }^{2}$ in particular introducing a form of 'special protection', similar to the former humanitarian one and which is valid for two years and can be converted into a resident permit for work. It has also revised the reception system SIPROIMI (now renamed SAI, Sistema di Accoglienza e Integrazione) by restoring a widespread reception system managed by the municipalities and allowing asylum seekers access to it. In addition, the Decree has strengthened services for asylum seekers' social inclusion.

Lastly, it is worth mentioning that in Italy many local Civil Tribunals have recognised the right to essential services and benefits (such as food vouchers) of

\footnotetext{
${ }^{2}$ In 2019 the government issued Decree Law No. 59, known as the Follow-up 'Security Decree', implemented by Law 77/2019, and which, in particular, toughened sanctions on NGO ships seeking to bring migrants rescued in the Mediterranean to Italy. Both the first Security Decree and follow-up decree were supported by Interior Minister Matteo Salvini.
} 
undocumented migrants during the current health emergency (Giammarinaro \& Palumbo, 2020). ${ }^{3}$

In Spain, the government also adopted measures to prevent targeted migrant workers from finding themselves in a condition of irregularity due to public administration delays or difficulties in renewing residence permits during the pandemic. In particular, to address labour shortages, support agricultural activities, and encourage the recruitment of new categories such as young third-country nationals in the agri-food sector, the Spanish government - through Royal Law Decree (RD) No. 13/2020, of 7 April 2020 - extended the validity of migrants' residence permits expiring during the lockdown period. In addition, young third-country nationals (aged between 18 and 21 years) in possession of regular documentation could benefit from being allowed to work in agriculture. This group consisted mainly of unaccompanied foreign minors (menores extranjeros no acompañados, also called 'mena') who turn 18 with their documents still pending resolution. This measure was updated and extended on 26 May 2020 by RD 19/2020, which allowed migrants employed in other sectors whose jobs had been affected by Covid-19 crisis to seek employment in agriculture. Furthermore, this RD provided a residence and work permit for two years (with a possible renewal of two more years and without sectoral limits) to young third-country nationals who obtained their first work contract thanks to the measure on work flexibility in the agricultural sector. This would allow these young migrants to potentially access long-term residence (OSEPI, 2020: 15).

In addition, the Spanish government adopted another wide-ranging measure extending permits to migrants already in possession of documents (Orden SND/421/2020, May 18). This measure established automatic renewal for six months following the expiration date of all temporary work, residence, and study permits expiring during the state of emergency or 90 days before its declaration. Furthermore, it provided for the renewal of residence cards of family members of EU citizens. However, even in this case, this measure did not apply to all migrants, excluding some categories such as, for instance, foreigners doing internships in the health sector - an exclusion that sounds quite bizarre in the middle of a public health crisis.

On the other hand, in June 2020, the government rolled out specific short-term social measures (Instrucciones) to stop more migrants falling into undocumented status. Income thresholds and other requirements were lowered to facilitate access to permit renewals, family reunification (Instrucciones DGM 4/2020), and the temporary residence permits based on social integration (arraigo social) (Instrucciones DGM 6/2020). Residence permits will also be renewed for those who are unemployed or receiving income support or the minimum living income, and for those who depend on their families.

Lastly, the Spanish government also issued a set of measures to protect asylum seekers who are in reception centres and who have pending administrative deadlines (Instrucción DGIAH 2020/03/20).

\footnotetext{
${ }^{3}$ See, for instance, Tribunal of Rome, Decision of 22 April 2020, R.G. No. 18957/2020.
} 
In general, it might be highlighted that, unlike the Italian regularisation plan, Spanish measures have consisted mainly of extending permits to migrants who were already in possession of documents. Therefore, they have not applied to migrants already in a condition of irregularity. At the same time, and perhaps related to the fact that they mainly consist of an extension, these measures do not rely on an employer-driven approach, as in the case of Italy. However, similarly to the Italian regularisation scheme, the Spanish measures have covered specific sectors and groups.

On 23 September 2020, the Spanish Congress refused to ask the government for a general and unconditional regularisation of undocumented migrants as proposed by the Republican Left of Catalonia party with the Confederal Parliamentary Group of Unidos Podemos, En Comú Podem, Galicia en Común. The initiative was rejected by the Spanish Socialist Workers' Party (PSOE), Popular Party (PP), Ciudadanos (Citizens), and the far-right Vox. The PSOE, in particular, argued that neither Spanish nor European legislation allows this measure, since both provide for 'individualised' and 'case by case' regularisation. This view has been significantly contested by Left parties, such as the Republican Left of Catalonia.

Like Italy, official data reveal that in Spain there are around 600,000 people in a condition of irregularity and precarity, including undocumented migrants and asylum seekers awaiting a decision on their case who could benefit from the move to grant them legal residency papers (Díez \& Casqueiro, 2020). As the RegularizacionYa campaign by civil society groups claims, rejecting the proposal for an unconditional regularisation is a missed opportunity that marks a significant step backwards for the rights of migrants in Spain.

On the other hand, important measures and court decisions have been adopted in Spain at the regional level to address the degrading living conditions of migrant farmworkers during the lockdown and pandemic crisis. For instance, the Administrative Court of Huelva (decision No. 345/2020) has allowed migrants living in informal settlements to register in the Municipality of Lepe (empadronamiento). This registration also lets irregular migrants access citizens' rights and is important for them to initiate the process of regularisation based on social integration (arraigo social) (Sainz, 2020). Furthermore, in Lleida and several municipalities in Catalonia, local authorities provided temporary shelters for farm workers. The regional government of Andalusia allocated over $€ 1.1$ million to guarantee minimum services to some 2200 inhabitants in the 79 settlements in the province of Almeria and another $€ 1.1$ million for 2200 people in 30 villages in Huelva. However, xenophobic and racist attitudes against migrant groups or institutional interventions also emerged, as in Albacete and Murcia (Palumbo \& Corrado, 2020).

In addition, unlike the Italian context, where there have been no actions to increase the institutional capacity to monitor during the pandemic, in Spain, in May 2020, the Minister of Labour provided for a strengthening of labour inspections in the agri-food sector during harvesting. This provoked strong reactions from agricultural businesses and employers who asked for the Minister's resignation, claiming that she attempted to stigmatise the sector (León, 2020). 
Finally, the participation of migrants, refugees and asylum seekers in the antiCovid-19 vaccination campaign is another relevant issue. In Italy, the vaccination plan does not make any specific reference to migrant people. This is a significant limitation considering that the access to health assistance is often problematic for migrants, especially for those who are in a condition of irregularity. In Spain, on the contrary, the vaccination strategy clearly states that vaccination could be applied to socially, economically and occupationally vulnerable groups, such as homeless people, people in the horticultural sector and undocumented migrants. The government of Aragon, for example, established the vaccination of temporary agricultural workers in May 2021 (Pérez, 2021).

\subsection{Concluding Remarks}

In many European countries, key and labour-intensive sectors such as agri-food rely on the employment of migrant workers, often in conditions of exploitation. The main factors driving the recourse to this labour force include agri-food restructuring processes, in particular imbalance of power in long supply chains. At the same time, stringent migration policies and labour market liberalisation processes play a crucial role in fostering the conditions of vulnerability of migrant workers and producing labour market segmentation based on gender, nationality, and legal status. This contributes to confining a migrant labour force to specific sectors and facilitates their continuous replacement and substitution by taking advantage of specific situations of vulnerability.

Such dynamics have been disclosed and simultaneously aggravated by the current Covid-19 crisis. In particular, the Covid-19 crisis has brought under the spotlight the essential character of migrant farmworkers and exacerbated their situations of vulnerability as it disproportionately impacted people most affected by discrimination and social exclusion.

By focusing on Italy and Spain, this chapter illustrates how, since the pandemic, labour shortages in the agri-food system have been offset both by a reserve army of migrant labour in situations of irregularity and vulnerability and also through work intensification and a further compression of workers' rights. This process has also involved encouraging the recruitment of new categories (such as young thirdcountry nationals) which, according to the dynamics of high labour turnover constantly reproduced in agriculture, sustains the need for a fresh and docile workforce. As the case of Huelva reveals, these processes have been compounded by gendered dynamics and power relations.

At the same time, the poor and degrading housing conditions have raised even more concern at this time of health emergency in terms of the dramatic consequences for individuals and public health. Contagions and risks of contagion of migrant agri-food workers are associated with overcrowded collective dormitories, extreme spatial mobility, reduced or non-existent protection measures at work and 
during transportation to employment, and the precarity and flexibility of labour contracts.

By reflecting the main political concerns and agri-food issues in the two countries, the Italian and Spanish governments have adopted different legal and policy responses to sustain the agri-food sector and address migrants' situations of vulnerability. In both cases, the responses of national governments have consisted primarily of short-term solutions, aimed at meeting seasonal labour demand and, as in the Italian case, at reducing the number of undocumented migrants working in agriculture or, as in the case of Spain, at preventing migrants' condition of irregularity. In Italy regularisation has had a limited impact, especially on the agricultural sector, resulting in a sort of failure. While it is true that Spain has taken some tentative steps towards more longer-term solutions, as in the case of measures for young thirdcountry nationals (OSEPI, 2020), even in this country, as in Italy, the question of a profound change in migration policies has remained unaddressed.

However, some differences have emerged in the institutional responses to address labour rights in agri-food systems before and during the pandemic. The Spanish government established a new increase in the minimum wage in agriculture, strengthened labour inspections in the countryside, and introduced reforms to contrast market pressures and unfair practices all along value chains, in line with EU Directive 2019/633 on unfair trade practices. In Italy, on the contrary, although the adoption of the Law n. 199/2016 on labour exploitation and illegal gangmastering, and the 2020-2022 Plan against exploitation in the agricultural sector marked an important step forward, no effective institutional initiatives have been adopted so far to support the implementation of specific provisions concerning the enforcement of labour rights and workers' transport and accommodation. Moreover, there is not yet a legal instrument to address unfair trade practices.

Since the outbreak of the Covid-19 crisis, it has been clear that agri-food sectors do not suffer from labour shortages, but from a shortage of rights for workers. Even if migrant farmworkers have been recognised as essential, their situations of vulnerability have been addressed in many countries, such as Italy and Spain, by implementing mainly emergency and short-term measures to mitigate the effects of the pandemic and provide them with some degree of social protection and temporary residence permits. However, as many trade unions, NGOs, and workers themselves have claimed, the response cannot be limited to this. The Covid-19 emergency, and all the inequalities and discriminations that the pandemic has made evident and exacerbated, should induce the adoption of structural interventions to overhaul a system that takes advantage of - and simultaneously engenders - the vulnerability of workers, especially of migrant workers. These interventions should be aimed at creating safe and legal entry routes for low- and medium-skilled workers, strengthening wages and labour rights, ensuring decent living conditions, developing welfare services, and supporting fair and sustainable agri-food supply chains. Only by moving in this direction might the pandemic constitute a crucial opportunity for a new drive to forge more labour and migrant rights compliant agrifood systems. 


\section{References}

Alston, P. (2020, February 7). UN Special Rapporteur on extreme poverty and human rights on his visit to Spain, 27 January'. UN Human Rights.

ANGED (Asociación Nacional Grandes de Empresas de Distribución). (2019). Informe anual, 2018. ANGED.

Arnalte-Alegre, E., \& Ortiz-Miranda, D. (2013). The 'Southern Model' of European agriculture revisited: Continuities and dynamics. In D. Ortiz, E. Arnalte, \& A. M. Moragues (Eds.), Agriculture in Mediterranean Europe between Old and New Paradigms (pp. 37-74). Emerald.

Caruso, F. (2016). Dal caporalato alle agenzie di lavoro temporaneo: i braccianti rumeni nell'agricoltura mediterranea. Mondi Migranti, 1(3), 51-64.

Cappellini, M. (2021). La pandemia ruba le braccia (straniere) all'agricoltura italiana. Il Sole 24 Ore, 20 Marzo, p. 14.

Corrado, A. (2016). Agrarian change and migrations in the Mediterranean from a food regime perspective. In A. Corrado, C. De Castro, \& D. Perrotta (Eds.), Migration and Agriculture. Mobility and change in the Mediterranean area (p. 311). Routledge.

Corrado, A., Caruso, F. S., Lo Cascio, M., Nori, M., Palumbo, L., \& Triandafyllidou, A. (2018). Is Italian agriculture a 'Pull Factor' for irregular migration - And, if so, why? Open Society European Policy Institute.

CREA. (2019). Il contributo dei lavoratori stranieri all'agricoltura italiana. CREA.

Cuesta, M. B., \& Sánchez, A. H. (2017). Inmigración y mercado de trabajo. Informe 2016. Observatorio Permanente de la Inmigración, 32, Ministerio de Empleo y Seguridad Social.

Díez, A., \& Casqueiro, J. (2020, July 9). Spain's Unidas Podemos party pushes for sweeping migrant regularization. El Pais.

Dines, N., \& Rigo, E. (2015). Postcolonial citizenship between representation, borders and the 'refugeeization' of workforce: Critical reflections on migrant agricultural labour in the Italian Mezzogiorno. In S. Ponzanesi \& G. Colpani (Eds.), Postcolonial transition in Europe: Contexts, practices and politics. Rowman and Littlefield.

Dongo, D. (2021). Pratiche commerciali sleali e legge di delegazione europea, analisi critica. GIFT https://www.greatitalianfoodtrade.it/mercati/ pratiche-commerciali-sleali-e-legge-di-delegazione-europea-analisi-critica

Echevarría, P. (2020, June 30). Crisis humanitaria de las temporeras marroquíes: Sin acceso a agua potable, cortes de suministro eléctrico y 'tutela salarial' en Fres Molinero SL. La Mar de Onuba, 30 June.

Elver, H. (2020, January 20-31). Italy: Food system exploits smallholder farmers and workers. UN Special Rapporteur on the right to food. UN food expert, UN Human Rights, Office of the High Commissioner.

Ero Straniero. (2021). Report monitoraggio regolarizzazione. https://erostraniero.radicali.it/wpcontent/uploads/2021/03/Report-monitoraggio-regolarizzazione_ERO-STRANIERO.pdf

European Commission. (2020a). Covid-19, Guidance on the implementation of the temporary restriction on non-essential travel to the $E U$, on the facilitation of transit arrangements for the repatriation of EU citizens, and on the effects on visa policy, C(2020) 2050 final.

European Commission. (2020b). Guidelines concerning the exercise of the free movement of workers during the COVID-19 outbreak, 2020/C 102 I/03.

Eurostat. (2019). The fruit and vegetable sector in the EU-A statistical overview. European Union.

Fondazione Ismu. (2020). Nuova regolarizzazione: le considerazioni di Fondazione Ismu, comunicato stampa dell'11.06.2020.

Giammarinaro, M. G., \& Palumbo, L. (2020). Covid-19 and Inequalities: Protecting the human rights of migrants in a time of pandemic. Migration Policy Practice, X(2 April-June), 21-26.

Geddes, A., \& Pettrachin, A. (2020). Italian migration policy and politics: Exacerbating paradoxes. Contemporary Italian Politics, 12(2), 227-242.

Hellio, E. (2016). 'They Know that you'll leave, like a dog moving onto the next bin'. Undocumented male and seasonal contracted female workers in the agricultural labour market of Huelva, 
Spain. In A. Corrado, C. De Castro, \& D. Perrotta (Eds.), Migration and Agriculture. Mobility and change in the Mediterranean area (pp. 198-214). Routledge.

ISMEA. (2020). Emergenza COVID-19. $3^{\circ}$ Rapporto sulla domanda e l'offerta dei prodotti alimentari nell'emergenza Covid-19.

Kantar. (2020). Balance de la Distribución y el Gran Consumo 2019, Kantar (Worldpanel Retail).

King, R., Lazaridis, G., \& Tsardanidis, C. (Eds.). (2000). Eldorado or fortress? Migration in Southern Europe. Macmillan.

León, I. (2020, May 15). El campo pide el cese de Yolanda Díaz tras enviar inspectores de trabajo en busca de 'esclavitud'. El Español.

Lewis, H., \& Waite, L. (2015). Asylum, Immigration Restrictions and Exploitation: Hyper-precarity as a lens for understanding and tackling forced labour. Anti-Trafficking Review, 5, 49-67.

Macrì, M. C. (Ed.). (2020). Le misure per l'emergenza Covid-19 e la manodopera straniera in agricoltura. CREA.

Martín, M. (2020, May 26). El Gobierno concederá un permiso de trabajo de dos años a los jóvenes inmigrantes que se han incorporado al campo. El País.

MAPA (Ministerio de Agricultura, Pesca y Alimentación). (2020). Avances de superficies y producciones agrícolas. Abril de 2020.

Ministero del Lavoro e delle Politiche Sociali - Mlps, Istituto Nazionale di Statistica - Istat, Istituto Nazionale della Previdenza Sociale - INPS, Istituto Nazionale per l'Assicurazione contro gli Infortuni sul Lavoro - INAIL, e Agenzia Nazionale Politiche Attive del Lavoro ANPAL. (2020). Il Mercato del Lavoro 2020. Una lettura integrata. Istat.

Ministero dell'Interno. (2020). Emersione dei rapporti di lavoro, 15 August. Governo Italiano.

Ministerio de Inclusión, Seguridad social y Migraciones. (2020a). Afiliados medios a la seguridad social, Mayo 2020.

Ministerio de Inclusión, Seguridad social y Migraciones. (2020b). Afiliados Extranjeros a la Seguridad Social, Mayo 2020.

Molinero Gerbeau, Y. (2018). La privatización de los programas de migración temporal en España como efecto poscrisis. Anuario CIDOB de la Inmigración, 2018, 284-306.

MSF (Medici Senza Frontiere). (2018). Fuori campo. Insediamenti informali, marginalità sociale, ostacoli all'accesso alle cure e ai beni essenziali per migranti e rifugiati. Secondo rapporto.

OSEPI. (2020). Towards an EU Toolbox for Migrant Workers. Labour mobility and regularisation in Germany, Italy, and Spain in 2020. Open Society Foundations.

Oxfam. (2018). Al giusto prezzo. I diritti umani nelle filiere dei supermercati italiani. Oxfam Italia.

Palumbo, L. (2020, June 8). The Italian Plan for Regularisation: Real Progress for Migrants' Rights? EUI MPC Blog.

Palumbo, L., \& Corrado, A. (2020). Covid-19, Agri-food systems, and migrant labour. In The situation in Germany, Italy, the Netherlands, Spain, and Sweden. Open Society Foundations.

Palumbo, L., \& Sciurba, A. (2018). The vulnerability to exploitation of women migrant workers in agriculture in the EU: The need for a human rights and gender based approach. Study commissioned by the European Parliament's Policy Department for Citizens' Rights and Constitutional Affairs.

Pedreño Cánovas, A. (2020). La cuestión jornalera entre dos crisis: condición inmigrante, desafiliación y riesgo de contagio. Sociología del Trabajo, 96, 1-15.

Perrotta, D. (2015). Agricultural day laborers in Southern Italy: Forms of mobility and resistance. South Atlantic Quarterly, 114(1), 195-203.

Perrotta, D. C. \& Sacchetto, D. (2014). Migrant farmworkers in Southern Italy: Ghettoes, caporalato and collective action. Workers of the World 1(5): 75-98.

Pérez, R. (2021). Aragón empieza a vacunar a los temporeros con una primera tanda de 2.500 dosis de Janssen. $A B C, 20$ Mayo.

Reigada, A. (2021). Collective Action, Experience and Identity in Global Agrarian Enclaves: The Case of Andalusia, Spain. In Martín-Díaz, E. \& Roca, B. (Eds). Migrant Organising: Community Unionism, Solidarity and Bricolage (pp. 154-180). Brill. 
Romera, J. (2020, February 6). La gran distribución solo compra el 7\% de la producción hortofrutícola Española. Eleconomista.es.

Rondi L. (2021). Il fallimento della sanatoria 2020 confermato da dati inediti sul settore domestico. Altreconomia, 25 Mayo.

Sainz, P. P. (2020, November 14). La Justicia obliga al Ayuntamiento de Lepe a admitir el empadronamiento en chabolas. El Salto.

Schiavone, G. (2020). La regolarizzazione nell'anno della pandemia: prime riflessioni. In IDOS Dossier Statistico Immigrazione 2020 (pp. 131-136). Centro Studi e Ricerche.

Summers, A. (2020, August 6). Los trabajadores agrícolas inmigrantes en España protestan en medio del aumento de COVID-19. World Socialist Web Site, wsws.org

Testore, G. (2020, May 18). Italian government adopts targeted regularisation for migrant workers. European Website on Integration.

Viruela, R., \& Torres Pérez, F. (2015). Flujos migratorios, crisis y estrategias de movilidad. Los inmigrantes ecuatorianos y rumanos en España. In F. Torres Pérez \& E. Gadea (Eds.), Crisis, Inmigración, Sociedad (pp. 37-72). Editorial Talasa.

Open Access This chapter is licensed under the terms of the Creative Commons Attribution 4.0 International License (http://creativecommons.org/licenses/by/4.0/), which permits use, sharing, adaptation, distribution and reproduction in any medium or format, as long as you give appropriate credit to the original author(s) and the source, provide a link to the Creative Commons license and indicate if changes were made.

The images or other third party material in this chapter are included in the chapter's Creative Commons license, unless indicated otherwise in a credit line to the material. If material is not included in the chapter's Creative Commons license and your intended use is not permitted by statutory regulation or exceeds the permitted use, you will need to obtain permission directly from the copyright holder. 